\title{
Plutonium Immobilization Rack and Magazine Preliminary Design
}

by

M. W. Stokes

Westinghouse Savannah River Company

Savannah River Site

Aiken, South Carolina 29808

This paper was prepared in connection with work done under the above contract number with the $U$. S. Department of Energy. By acceptance of this paper, the publisher and/or recipient acknowledges the U.S. Government's right to retain a nonexclusive, royalty-free license in and to any copyright covering this paper, along with the right to reproduce and to authorize others to reproduce all or part of the copyrighted paper. 


\section{DISCLAIMER}

This report was prepared as an account of work sponsored by an agency of the United States Government. Neither the United States Government nor any agency thereof, nor any of their employees, makes any warranty, express or implied, or assumes any legal liability or responsibility for the accuracy, completeness, or usefulness of any information, apparatus, product, or process disclosed, or represents that its use would not infringe privately owned rights. Reference herein to any specific commercial product, process, or service by trade name, trademark, manufacturer, or otherwise does not necessarily constitute or imply its endorsement, recommendation, or favoring by the United States Government or any agency thereof. The views and opinions of authors expressed herein do not necessarily state or reflect those of the United States Government or any agency thereof.

This report has been reproduced directly from the best available copy.

Available to DOE and DOE contractors from the Office of Scientific and Technical Information, P. O. Box 62, Oak Ridge, TN 37831; prices available from (423) 576-8401.

Available to the public from the National Technical Information Service, U. S. Department of Commerce, 5285.Port Royal Road, Springfield, VA 22161. 


\section{DISCLAIMER}

Portions of this document may be illegible in electronic image products. Images are produced from the best available original document. 
WSRC-TR-98-00333

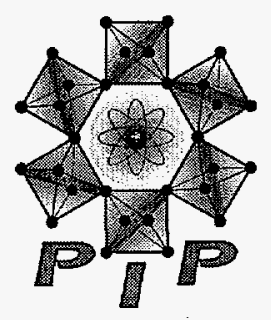

\section{Plutonium Immobilization}

\section{Rack \& Magazine Preliminary Design (U)}

September 30, 1998

Westinghouse Savannah River Company Savannah River Site Aiken, SC 29808 


\section{Plutonium Immobilization \\ Rack \& Magazine Preliminary Design (U)}

Approvals

Manchang

Clyde ard, SRTC

Technical Lead
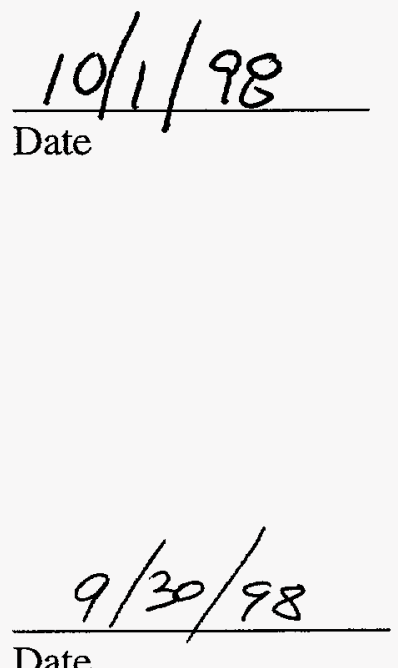

Date

$\frac{9-30-98}{\text { Date }}$

Level 3 Manager

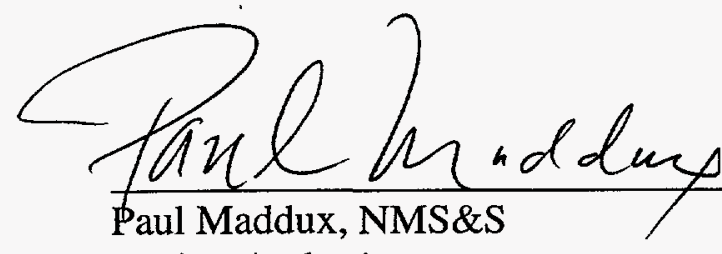

Design Authority 


\section{Plutonium Immobilization Rack \& Magazine Preliminary Design (U)}

The following Plutonium Immobilization Can-In-Canister Team members contributed to this report.

Lee Hamilton

SRTC/EES

Harriet Haynes

SRTC/EES

Greg Hovis

SRTC/EES

Robert Jones

NMS\&S

Eric Kriikku

SRTC/EES

Clyde Ward

SRTC/EES

Mitchell Stokes

SRTC/EES 


\section{Plutonium Immobilization \\ Rack \& Magazine Preliminary Design (U)}

Table of Contents

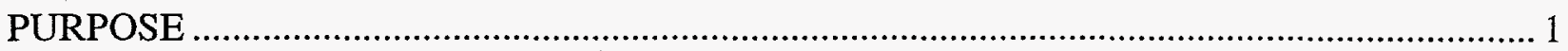

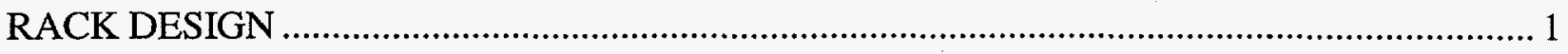

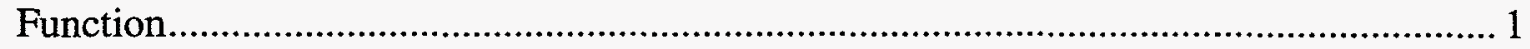

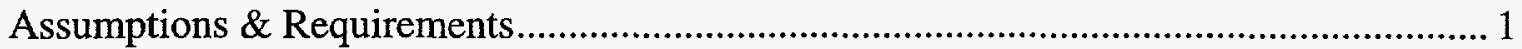

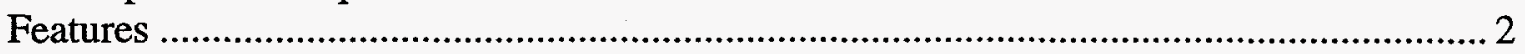

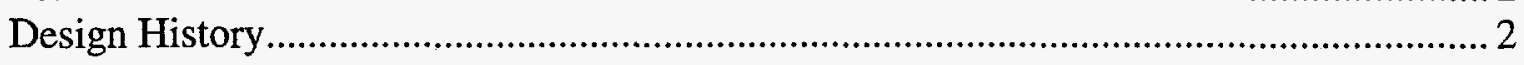

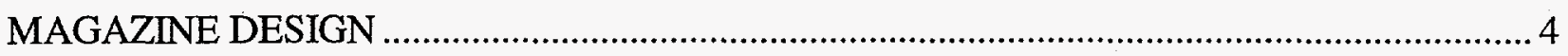

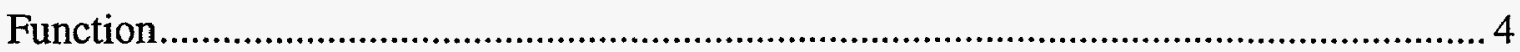

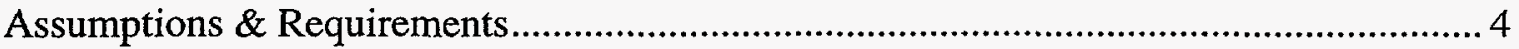

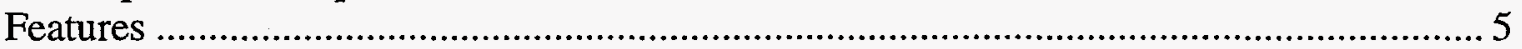

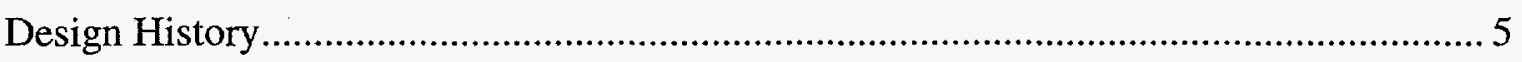

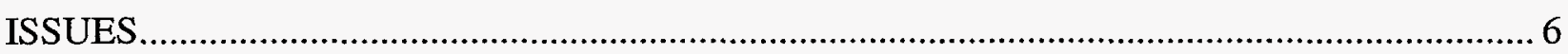

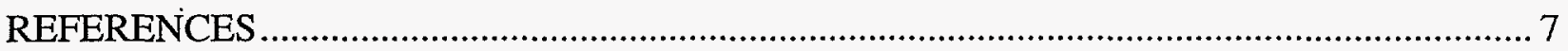

\section{LIST OF ATTACHMENTS}

1. Rack Weldment

2. Scalloped Plates

3. Base Plate Details

4. Latch Details

5. Magazine Assembly \& Details
EES-22624-R3-014

EES-22624-R1-019

EES-22624-R1-020

EES-22624-R1-021

EES-22624-R1-011 


\section{PURPOSE}

The purpose of this report is to document our current preliminary design for the Can-in-Canister rack and magazine. Since this is a developmental project with testing still ongoing, these designs will probably change as we become more knowledgeable of the functions, reliability, and cost of these designs.

\section{RACK DESIGN}

\section{Function}

In the Plutonium Immobilization Project, seven magazines will be remotely loaded through the neck of a DWPF canister and placed into positions determined by an internal framework, or "magazine rack" inside the canister (see attachment 1). The magazine rack serves several purposes: (1) It keeps the seven magazines in a pre-determined, symmetric orientation inside the DWPF canister; (2) The rack provides both lateral and vertical latching to reduce the possibility of magazines leaving their positions; (3) The rack lends strength during canister handling, transportation, and glass pouring; and (4) The rack contributes to non-proliferation by supplying a structural connection for the seven magazines in the glass-metal matrix.

\section{Assumptions \& Requirements}

A conceptual design for the magazine rack is presented herein. A number of assumptions were used in developing this design, and they are listed below:

1) The rack will be installed inside the DWPF canister during canister fabrication.

2) The rack will hold seven magazines ( 3.5 " diameter, $87 "$ tall).

3) The magazine will hold four cans (3" diameter, 20" long).

4) Magazine loading will be performed through the neck of the canister using a jointed arm robot.

5) Vertical and lateral latching is required on the magazine rack.

6) Vertical latches are not required at each row of cans. Latches are only required to meet transportation and handling loads. At this time, lateral latches will only be installed at two rows of cans, the first (top) row and the third row.

7) There will be one scalloped plate installed at each can level. One scalloped plate will be provided for each row of cans to provide structural support. The plates also provide a potential increase in proliferation resistance.

8) The rack's mass will be kept to a minimum for thermal considerations.

9) Where possible, the rack will minimize resistance to glass flow.

10) A minimum of 2" of clearance will be provided between the rack bottom plate and the canister bottom.

11) The rack will provide a minimum of 2" of clearance between the magazine o.d. and the canister i.d.

12) No portion of the rack or installed magazine shall exceed a height of 91 " which is the minimum procedural fill height for DWPF (as measured from the canister bottom). 


\section{Features}

The magazine rack is shown on the accompanying drawings, attachments 1 through 4 . Four scalloped plates and one bottom plate are joined by seven vertical 3/4" solid 304 series stainless steel round bars. Each plate is constructed of $1 / 4$ " 304 series stainless steel plate. Plates are cut as shown to minimize mass and minimize resistance to glass flow. Lateral "butterfly" latches are installed on two of the scalloped plates (top and third from top).

The rack's bottom plate has a 9" opening in its center for glass flow. Seven "funnel" openings provide the bottom support for the magazines. The funnel openings accept the cone sections at the lower end of the magazines. In this concept, vertical latching is achieved at the cone/funnel interface using snap rings. A 2.5 " carbon steel snap ring is installed in each funnel groove of the magazine rack. When the magazine is installed, a groove on the cone section accepts a portion of the snap ring, locking the magazine to the rack. The lower plate is supported $\sim 3$ " above the bottom of the canister with seven radial struts. The struts match the contour of the DWPF canister bottom and have large cutouts to reduce mass and to permit glass flow.

\section{Design History}

The basis for the rack design was evolving as the conceptual design for the Plutonium Immobilization Project was being developed. The facility layout and processes were chosen in parallel with concepts for pucks, magazines, cans, racks, and remote equipment. A primary influence on rack design was the equipment and operations proposed in the canister loading area of the facility. Other direct influences on the rack design are captured in the assumptions listed above under "Rack Design."

The facility layout and operating equipment establish some important rack design considerations. As presently envisioned DWPF canisters with the rack pre-installed enter the facility's canister loading area on a chain-driven rail cart, identical to the DWPF transport cart. While in the loading position, canisters are stationary, in a vertical orientation, and do not rotate. A telescopic, four degree-of-freedom robot is used to load each canister with seven magazines. The robot is equipped with a tool-change plate that carries a manipulator arm and gripper arrangement for magazine handling operations. The manipulator adds an extra-degree-of freedom for a total of five. The portion of the robot that enters the canister is shown in Figure 1 below.

The robot is capable of three motions once inside the neck of the canister. Two rotations $\left(\theta_{1}\right.$ and $\theta_{2}$ ) and a translation $(\mathrm{z})$. During loading operations, the $\theta_{1}$ rotation is used to align the manipulator arm in the correct radial orientation. The $\theta_{2}$ rotation is used to move a magazine to the proper radial position, and the $\mathrm{z}$ translation is used to lower the magazine to its resting elevation. An objective of the rack design was to take full advantage of these motions to perform magazine loading and latching.

An additional rack design objective was to provide a clear and open center region to allow for unobstructed glass flow and $\theta_{2}$ rotation. The magazine's radial positions were placed as far from the canister center as possible without exceeding the minimum two-inch clearance limit between magazines and the canister wall. 


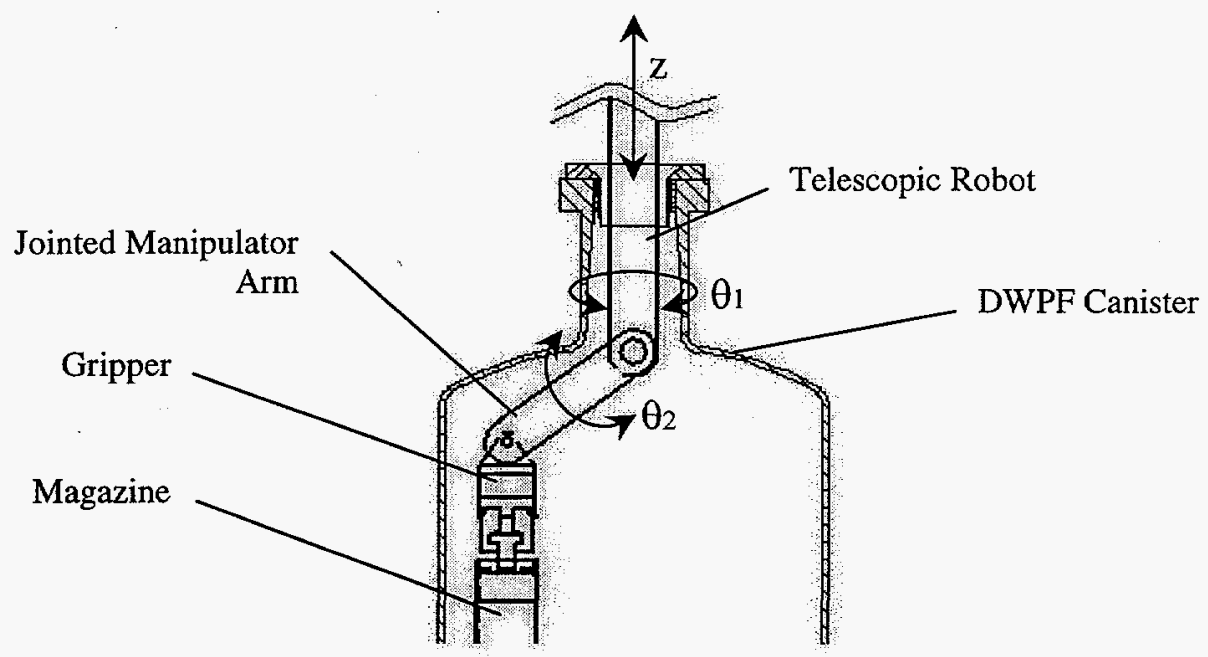

Figure 1. Sketch of canister loading equipment and motions.

To keep the rack light and strong, a framework of horizontal plates connected by vertical support rods was the configuration chosen for the rack design. All parts are made of 304 series stainless steel, which matches the DWPF canister material. There are four scalloped plates and one base plate.

A customer requirement specified the need for one scalloped plate per product can in a magazine. In the current design there are four 20 " cans per magazine, thus four scalloped plates are used in the rack design. The scalloped plates are positioned such that they align with the center of each can. The first scalloped plate is positioned roughly 10" above the bottom plate, followed by three more spaced 20" apart.

At the bottom of the rack is the base plate. The base plate carries the weight of the magazines, serves an alignment function for magazines, and provides some magazine lateral stability as a result of the cone-nipple arrangement on the bottom of the magazines. The base plate is supported by seven radial struts welded to the bottom of the base plate. In order to distribute the load of the rack and magazines, and to provide a stable base, the strut's bottom surface matches the contour of the bottom of the DWPF canister. The struts have large openings for glass flow and mass reduction. A 9" diameter hole in the center of the base plate permits unobstructed glass flow to the bottom of the canister. At the lowest clearance location, there is $\sim 3$ " between the base plate and the bottom of the canister.

The plates are connected by seven vertical 3/4" solid stainless steel rods which are positioned between magazine locations. The rods start at the radial struts on the bottom, and end just above the top most plate. Holes are drilled in the plates to allow the rods to pass through, and the plates are welded to the rods at the proper axial location.

One purpose of the rack is to provide some type of lateral latching that keeps the magazines in a vertical orientation during handling and transportation. Several lateral latching concepts were 
considered. These included spring loaded latches, "clam-shell" devices, linked mechanisms, and gravity latches. At the beginning of the design process, the design team decided to avoid spring actuated equipment due to reliability arguments. Clam-shell devices are reliable and selfactuating, but it is difficult to ensure that they remain open during canister handling operations prior to magazine loading. Mechanical linkages were considered (e.g. latching that actuates under the weight of the magazine), unfortunately these devices increase the number of moving parts in the rack. The "butterfly" or gravity method of magazine lateral latching was chosen after considering the concepts above. In scoping tests the gravity latches proved to be simple, reliable, and easy to manufacture. These latches engage and capture the magazine near the end of the manipulator arm's $\theta_{2}$ rotation. The rack's lateral latches are designed to resist magazine lateral motion. They will be installed at a minimum of two scalloped plate locations and may be installed at all four. Cold pours scheduled for the February " 99 time frame will test both configurations and assist in finalizing this aspect of the design.

In the proposed rack design, magazine vertical latching occurs following lateral latching. Once latched in the appropriate radial position, the telescopic section of the robot provides the necessary downward (or $-\mathrm{z}$ ) motion to bring the magazine to its lowest resting position. At or near the resting position, vertical latching occurs. Vertical latching is intended to prevent (or minimize) axial motion of the magazines during transportation activities. In the current design, vertical latching is achieved using a snap ring connection at the bottom end of the magazine. A snap ring attaches the cone section of the magazine to the funnel in the base plate. While other methods of vertical latching are currently being developed, the snap ring connection has been tested and appears to be a very reliable and secure latching method.

\section{MAGAZINE DESIGN}

\section{Function}

In the Pu Immobilization facility, pucks will be seal welded into bagless transfer product cans. Automatic loading equipment will then put four cans into a magazine, which holds cans in the same way a flashlight holds batteries. Magazines serve the following functions in the immobilization program:

- Group cans into a cylindrical form suitable for insertion through the DWPF Canister throat

- Hold cans in place inside the canister during transport and glass pouring

- Consolidate cans into a bundle to minimize handling in the PIP

\section{Assumptions \& Requirements}

Some assumptions used in developing the magazine concept follow:

1. Each magazine holds four 20 " cans, each loaded can weighs approximately $25 \mathrm{lbs}$.

2. Magazines will have the maximum amount of open area in the barrel to minimize resistance to glass flow.

3. After pouring, glass will surround the cans inside the magazine.

4. Magazine length cannot exceed 87."

5. OD cannot exceed $35 / 8$." 
6. Each magazine must be remotely loaded with cans and remotely installed into the rack inside the DWPF canister.

7. Cans are not required to be individually restrained within the magazine.

8. The magazine interior must be amenable to cans remotely sliding into place.

9. The magazine exterior must be amenable to remote insertion through a protective funnel in the DWPF canister neck.

10. The mechanical strength of the magazine must be adequate to allow remote handling of the magazine loaded with product cans.

\section{Features}

The magazine is shown on attachment 5. Either 3" Sch 10 stainless steel pipe or 3.5 " $x .120$ wall tubing is the material of construction for the barrel. The slots are either cut or milled into the barrel side wall using laser, plasma torch or milling machine. Alternate manufacturing methods are being evaluated. Both ends are machined from 304 SS solid stock. The "cone end" of the magazine is held into place with a snap ring to retain the cans after they have been placed in the magazine. The top mushroom end is fixed permanently and is used for remote handling. The magazine ID is 3.25" nominal to provide clearance for ease of loading and for maximizing glass flow between the magazine and can walls.

\section{Design History}

Canister loading with magazines loaded with product cans was identified early in the project as the preferred method for loading the product cans into the DWPF canister. SRTC and NMSS identified and evaluated over 20 concepts (ref.1 \& 2) for loading product cans into the magazine. After carefully analyzing all the concepts, EES chose a rigid magazine as the best method to remotely load cans into DWPF canisters.

To ensure the feasibility of "through the throat" magazine manipulation inside a DWPF canister, SRTC conducted a remote loading test using a test magazine constructed of 3" Sch40 pipe and having prototypic loaded weight and overall dimensions. This successful test yielded the current designs for the magazine's mushroom top and "cone in cup" bottom.

Two methods to insert cans into magazines were developed: (1) end loading and (2) side loading. End loading requires cans to be pushed into a horizontal or vertical magazine and secured by snapping on either the magazine top or bottom piece. Side loading magazines have a door through which each can is inserted into an inclined magazine and then allowed to slide into position motivated only by gravity. After the last can is in place, the loader snaps the door closed. SRTC also considered magazine construction and identified three possible forms:

- Welded wire frame (like a shopping cart)

- Wire mesh

- Perforated pipe

SRTC prepared basic requirements and sketches for side and end loading magazines, then submitted them to 25 job shops specializing in wire frame, perforated metal and expanded metal fabrication, as well as general fabrication shops. (The requirements were kept basic to encourage vendors to use their own expertise and experience.) Five vendors submitted designs for 10 magazines: 2 perforated pipe end loaders, 2 perforated pipe side loaders; 1 wire mesh side 
loader, 1 wire mesh end loader, 2 welded wire side loaders, and 2 welded wire end loaders. All ten designs were purchased.

In preparation for testing actual magazines, SRTC developed an incline loading mockup and demonstrated loading a magazine with gravity as the motive force. SRTC also designed and began fabricating a test bed for demonstrating forced horizontal and vertical loading. SRTC used Finite Element Analysis (ref.3) to analyze and modify vendor-submitted welded wire and wire mesh designs, however the models showed they could not be made strong enough to adequately support the loads.

Vendor feedback showed one of the greatest problems to overcome in magazine design was the magazine closure. Wire magazines offered the greatest challenge. After experimenting with end closures consisting of tabs, wires, ball detents, and retaining rings, it was clear that retaining rings were the most reliable remote closure with the added benefit of taking up the least space.

None of the vendors produced a wire magazine with an acceptable and remotable side door. The opening in the magazine for the door created a weak area that produced undesirable bending of the loaded magazine. The doors were either complex, weak or had parts outside of the design envelope. SRTC chose to cease development of the side load option and concentrate on end loading.

SRTC tested the vendor-supplied magazines to determine their suitability for remote handling. The test included remotely picking up the loaded magazine with a PAR gantry robot, moving it through a DWPF canister throat mockup into the loaded position, and then returning it to a test stand. Only two magazines worked as designed, both of which were pipe concepts from the same vendor. All six wire magazines were either too flimsy, too easily deformed, too costly, or too inconsistent in dimensions for further consideration. Two of the wire forms were damaged in shipping. Another collapsed under the weight of a column of cans before the robot picked it up. Additionally, testing also showed that wire form and wire mesh magazines hang out of plumb when loaded with cans, making them difficult to manipulate. (Pipe magazines hang very close to plumb when filled with cans.) Finally, wire forms are much more difficult to restrain in the rack due to their excessive flexibility and construction which promotes hanging up on the rack latches.

After evaluating the ten magazines, SRTC combined the best features of all with our own ideas to produce the current designs for a bottom load magazine constructed from pipe or tubing with generous openings for glass flow. LLNL will model the pipe magazine to identify glass flow characteristics. Glass pour tests will be conducted with scale melter equipment to ensure there are no voids in glass poured around the magazine and to check for adequate strength in the magazine during the pour. Several iterations of the current basic design will be submitted for the pour tests. The design will vary in the size and shape of the slots and thickness of the magazine enclosure.

\section{ISSUES}

1. The main issue with both the rack and magazine design is whether or not these designs will allow for proper glass flow and provide adequate mechanical strength during glass pouring.

2. An alternate method for vertical latching in the rack is being evaluated that would be easier to manufacture. 
3. Manufacturing methods and tolerances for the magazine design are being evaluated.

4. Thinner wall sections for the magazine barrel are being tested.

\section{REFERENCES}

1. Minutes of Can-In-Canister Concept Review, E-mail from GL Hovis, Savannah River Site, Aiken, SC 29808 (12/17/97).

2. Magazine \& Canister Loading Technique, E-mail from GL Hovis, Savannah River Site, Aiken, SC 29808 (1/5/98).

3. Plutonium Immobilization Concept Magazine FEA, PEC-EAT-98-0022, Savannah River Site, Aiken, SC 29808 (6/10/98). 


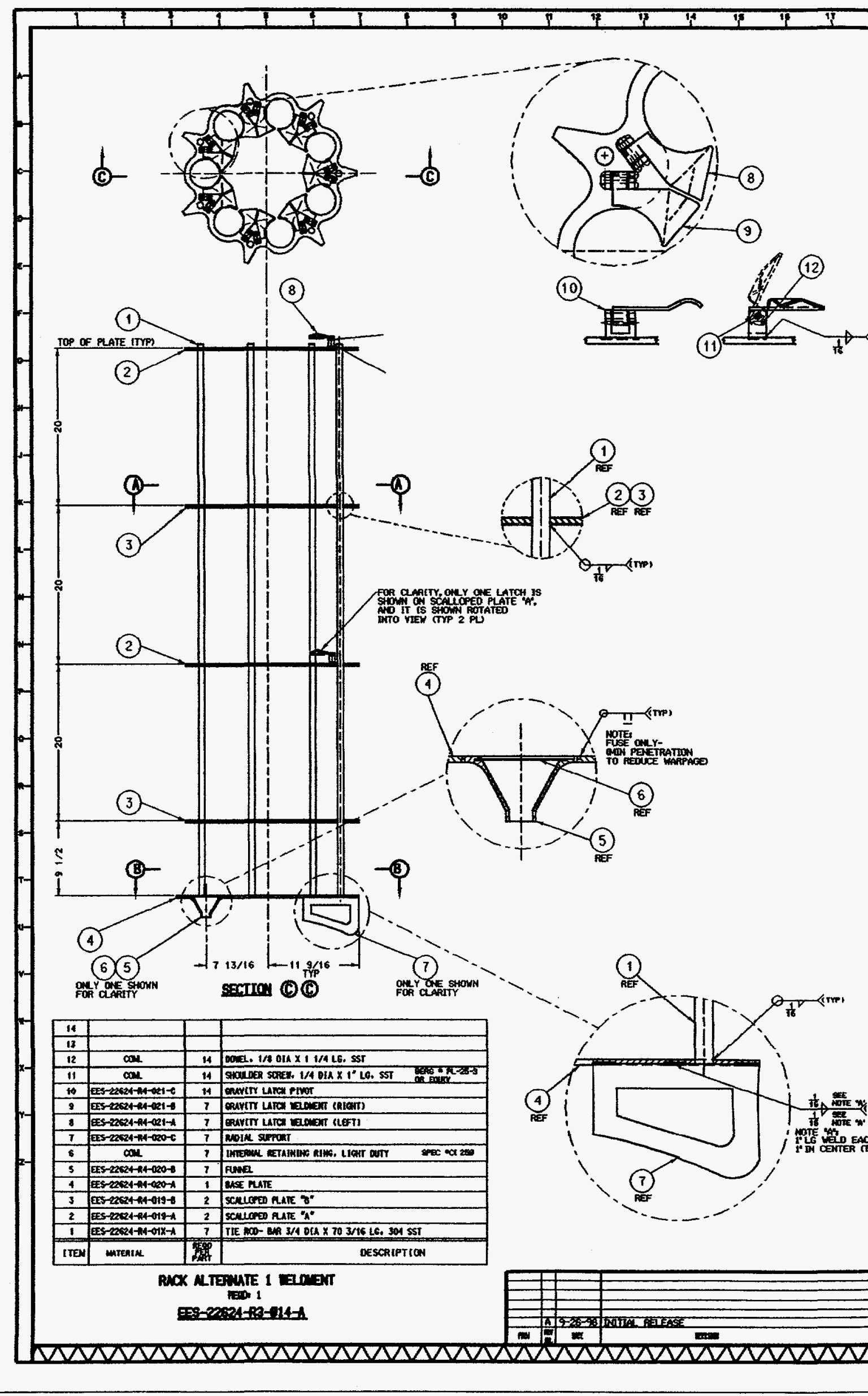




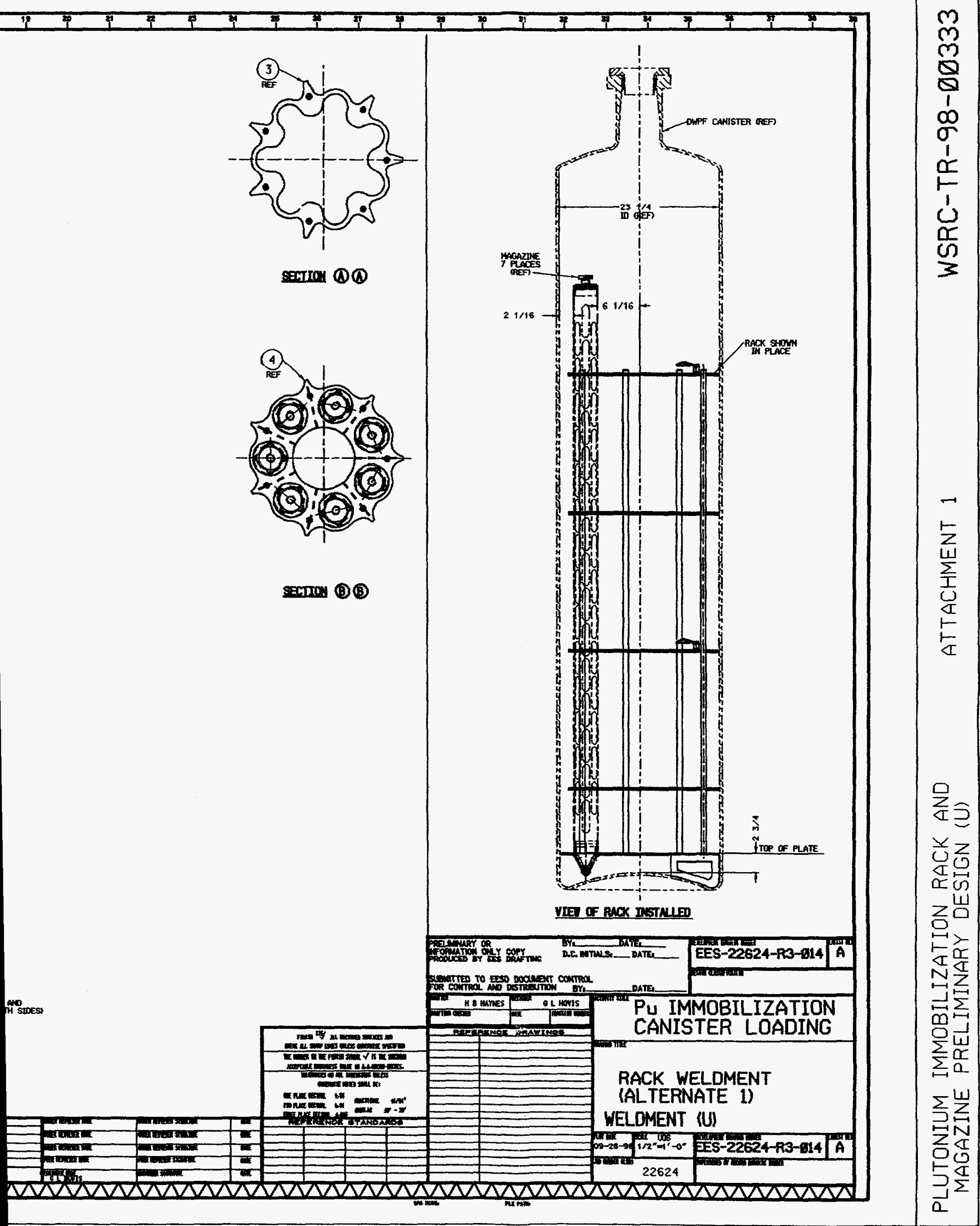




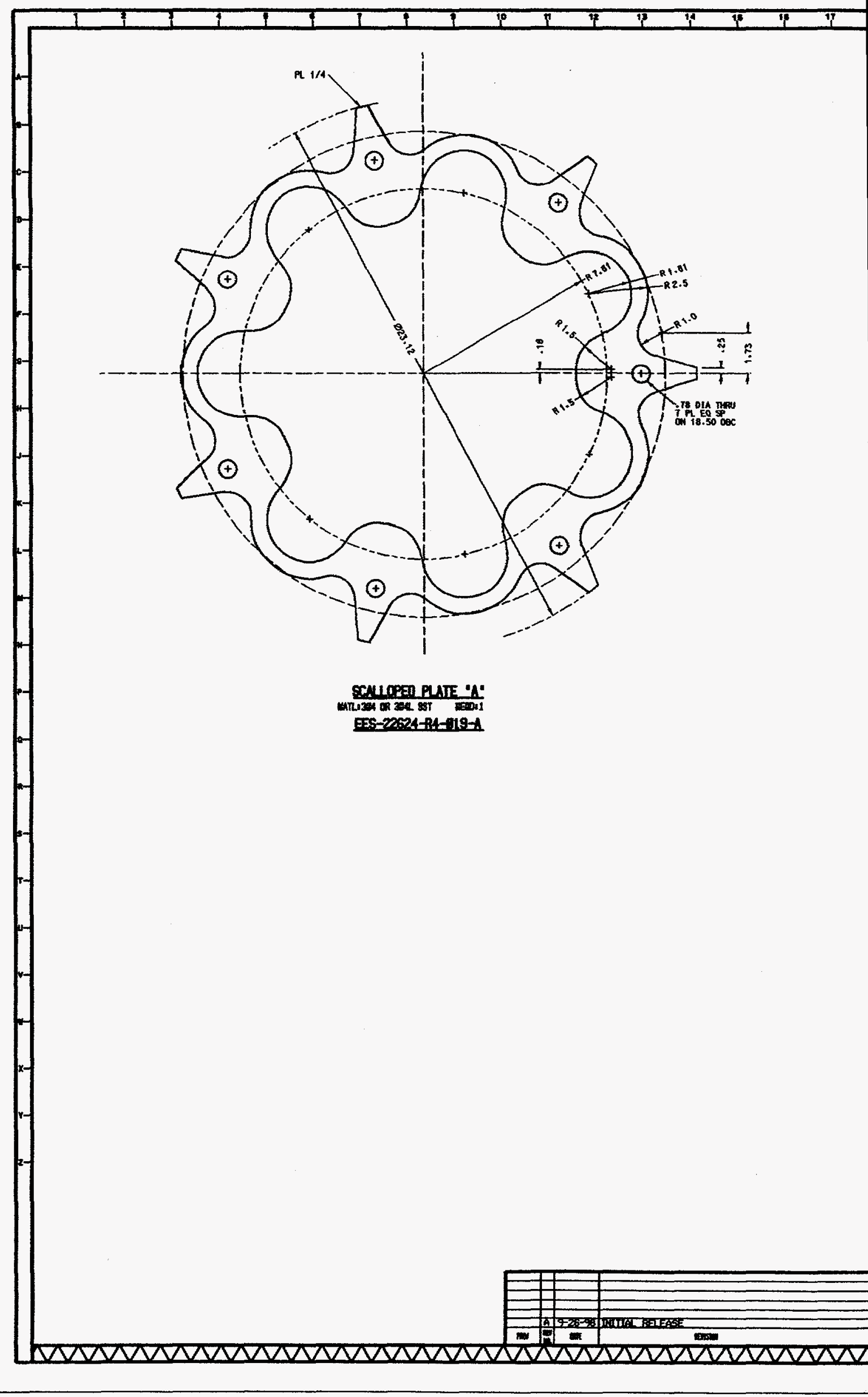




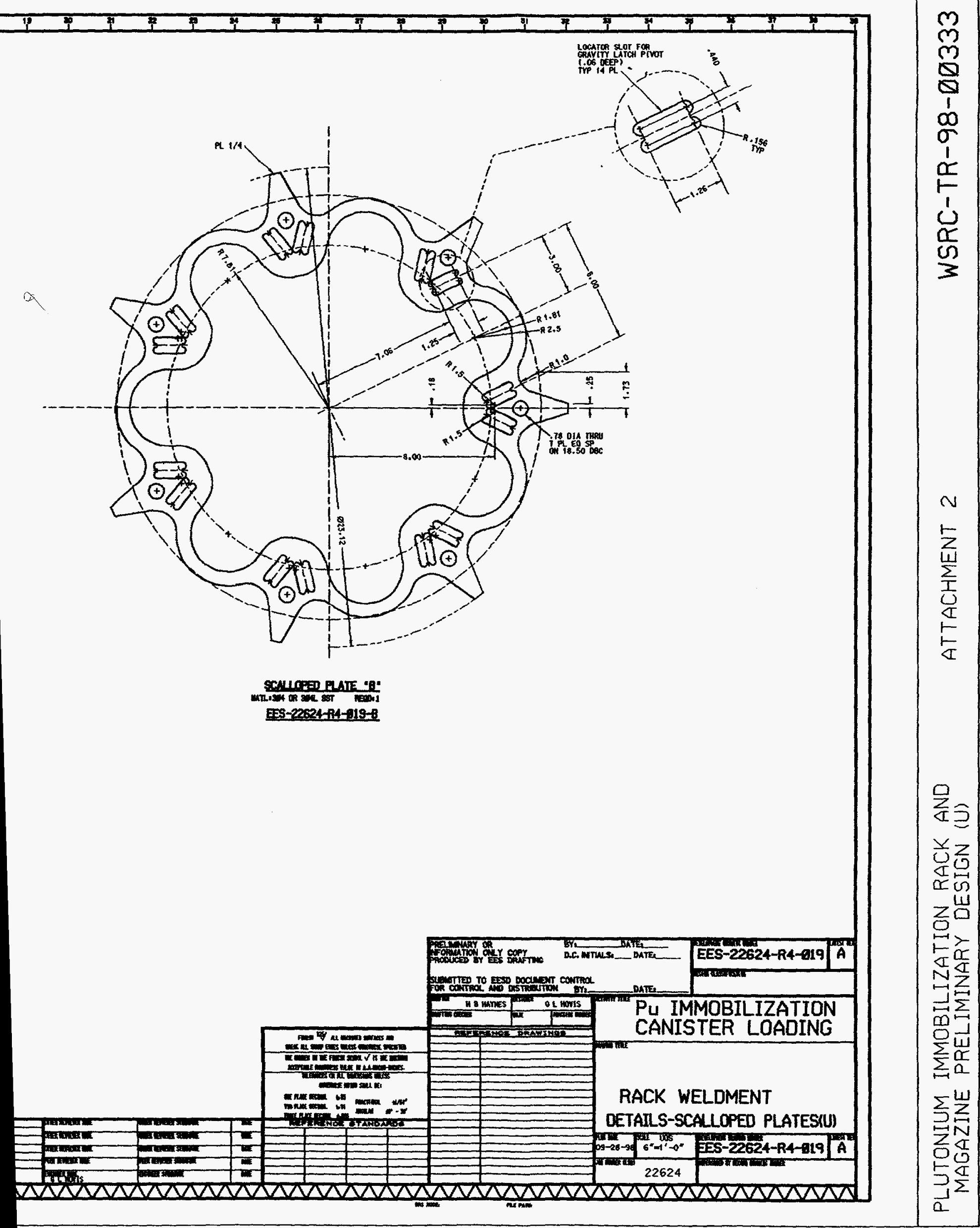




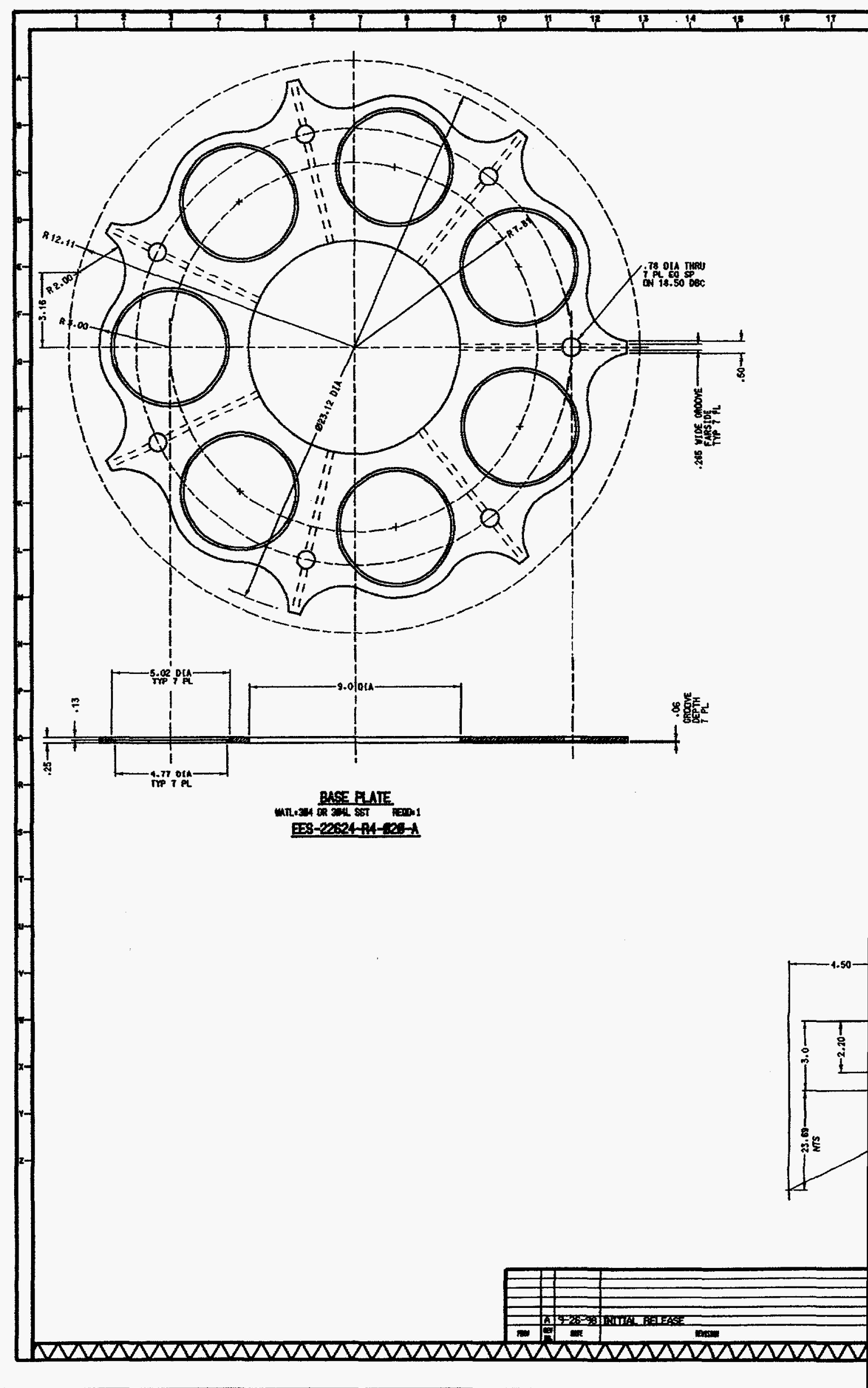




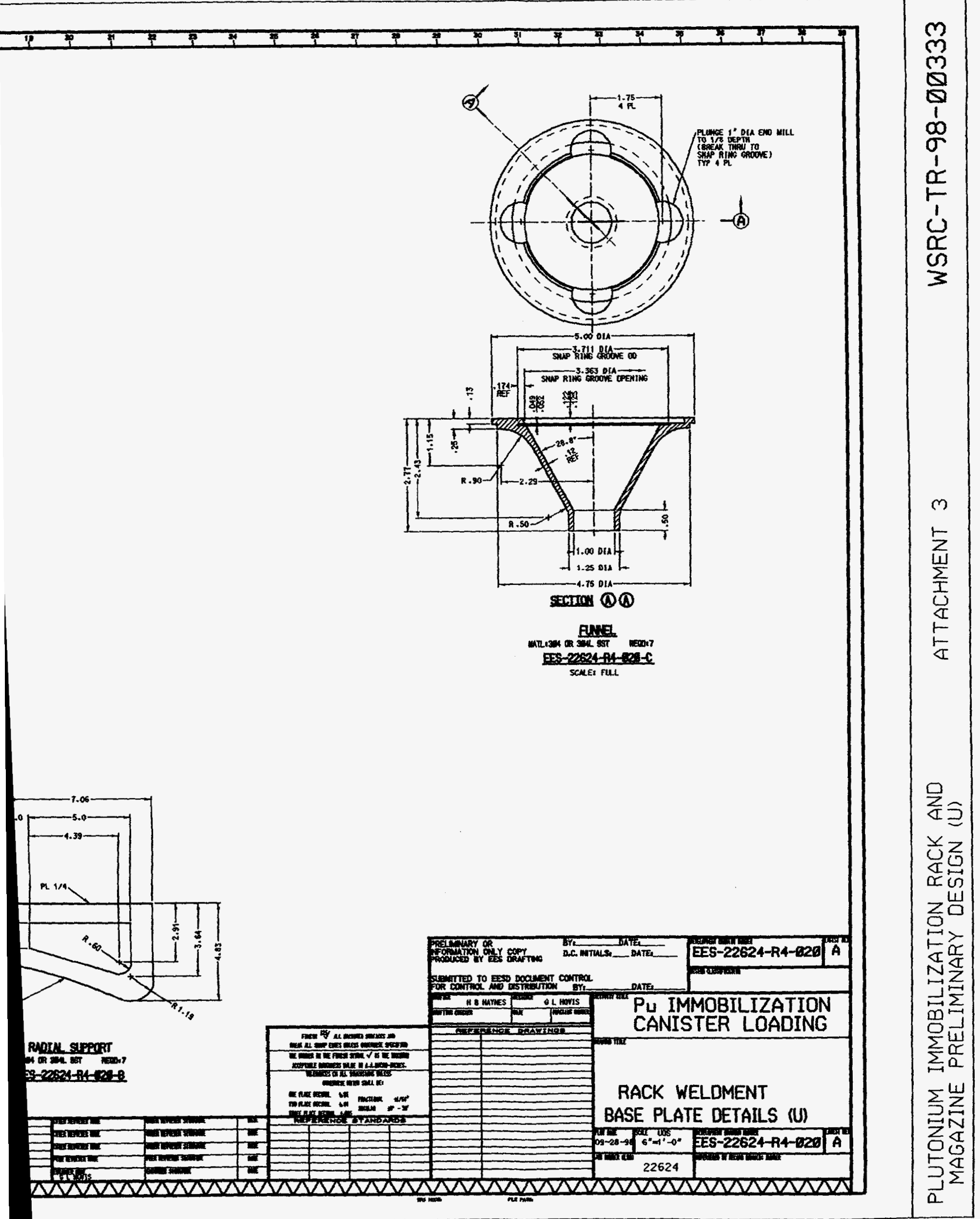




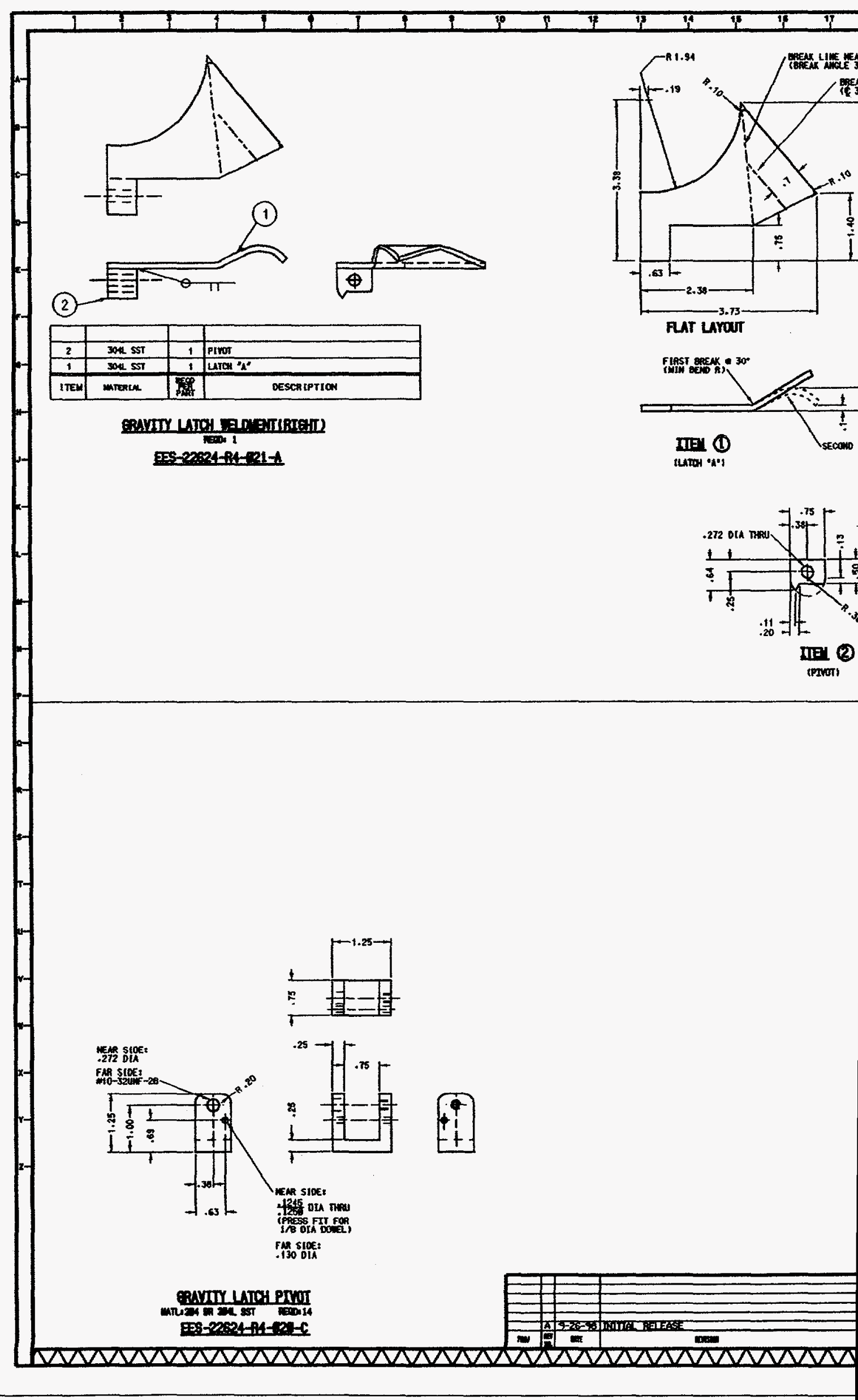




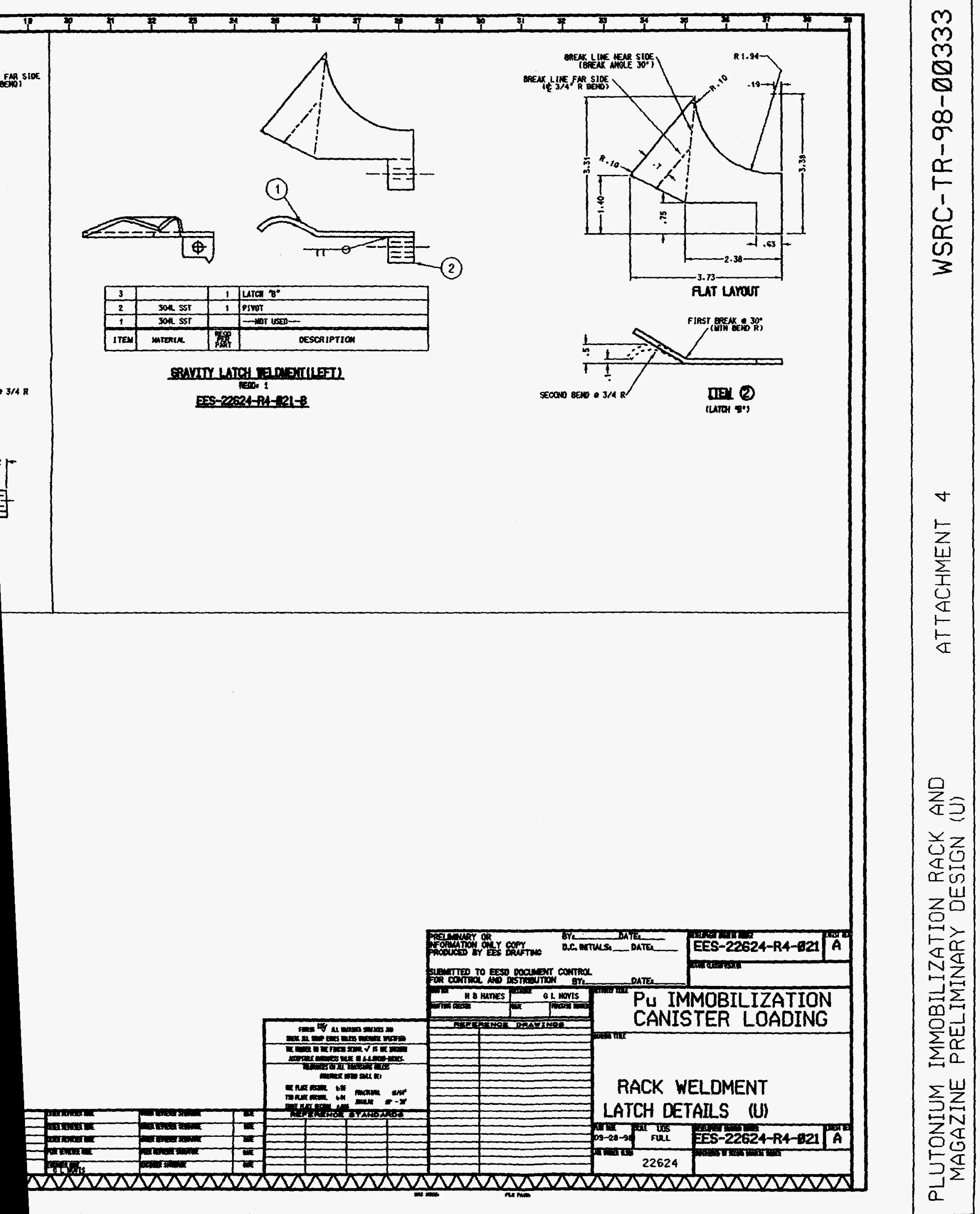




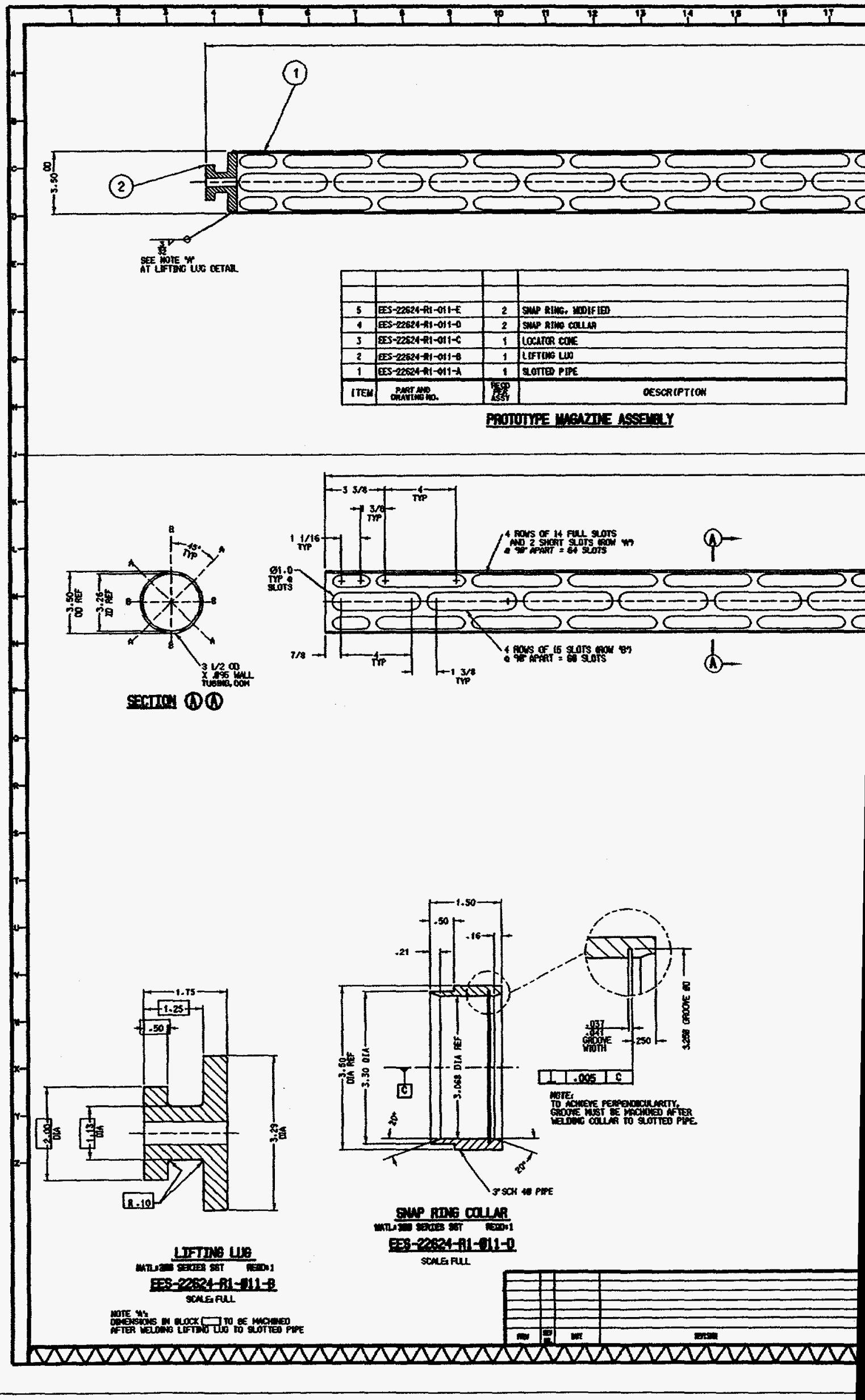


